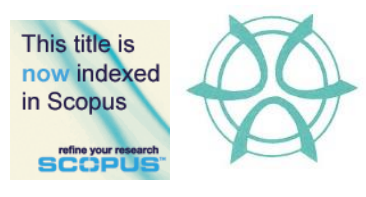

PLANNING MALAYSIA:

Journal of the Malaysian Institute of Planners

VOLUME 16 ISSUE 1 (2018), Page 131 - 140

\title{
MAPPING THE LANDSCAPE CHARACTERS ALONG A RURAL ROUTE FOR TOURISM
}

\author{
Nur Amirah Abdul Wahab ${ }^{1,}$ Khalilah Zakariya ${ }^{2}$, Putri Haryati Ibrahim ${ }^{3}$, \\ \& Illyani Ibrahim ${ }^{4}$ \\ ${ }^{1,2,3,4}$ Kulliyyah of Architecture and Environmental Design, \\ INTERNATIONAL ISLAMIC UNIVERSITY MALAYSIA
}

\begin{abstract}
The scenic landscape characters along driving routes have been acknowledged by numerous studies to be important in planning for rural tourism. Landscape characters shape the setting and ambience of a place. This study focuses on mapping the landscape characters along a rural route as a way to identify potential characteristics to be conserved and enhanced for tourism. The case study area covers the Kuala Selangor to Sabak Bernam route, which is part of a federal route that runs along the west coast of Peninsular Malaysia. Using landscape character mapping, observation and landscape character assessment (LCA), mapping was conducted to identify and analyse the landscape characters along the route based on the physical, cultural and environmental attributes. It is found that each segment along the route has its own attributes and the physical images based on their activities and environment. This study found that the rural route has a unique and distinctive rural landscape identity that needs to be integrated with the planning of infrastructure and road system, in order for it to increase tourism activities.
\end{abstract}

Keyword: landscape character assessment (LCA), rural tourism, tourism route 
Nur Amirah Abdul Wahab, Khalilah Zakariya, Putri Haryati Ibrahim, \& Illyani Ibrahim

Mapping the Landscape Characters Along A Rural Route for Tourism

\section{INTRODUCTION}

Rural tourism is widely acknowledged by the tourism industry as activities that contribute to the income generation of rural areas. Planning for rural tourism also encourages the conservation of cultural and natural heritage, such as traditional villages, cultural landscapes and landscape features. The rural setting becomes the main attraction for tourists, where the selection of scenic driving routes is often selected based on the experience that the route can offer.

Through the rural tourism activities, visitors have the opportunity to experience the village cultures with the wide range of attractions and activities offered by the local people. Some of the most common rural tourism activities are those related with agriculture, nature and open spaces, and settings with lowlevel of development, traditional houses and the local lifestyles (Irshad, 2010). The rural setting attracts tourists from the urban area because it offers them a view of the natural environment, opportunities to engage in local activities and experience culture, traditions, history and heritage of a place. Jaal and Abdullah (2012) suggested that the landscape characters are part of the key elements that shape the cultural identity and foster the quality of life of the rural community. Rural tourism characters could benefit the local people in terms of income generation by attracting the visitors to their village and promote their local products.

While the benefits of rural tourism have been broadly recognized by various researchers and agencies, rural attractions are often located far away from the city and time-consuming to be accessed. As a result, visitors tend to use the faster routes, such as the highways. Consequently, the passive flow of visitors into the rural areas results in less vibrant rural tourism activities. With a holistic landscape planning, the rural route can actually offer a more scenic journey while at the same time offer activities for visitors to make their road trip more fulfilling and enriched.

The aim of this study is to identify the landscape characteristics of the rural route along Kuala Selangor and Sabak Bernam, which has potential as a tourism route connecting the states of Selangor and Perak. The landscape characters are mapped in order to recognize the major characteristics that contribute to the setting and rural image of this route with reference to the landscape character assessment (LCA).

\section{BACKGROUND STUDY}

\section{Indicators of the Vibrancy of Rural Area}

The location of rural attractions that is far from the hustle and bustle of the city is one of the factors that make the rural area vibrant and appealing. According to Hasuike, Katagiri, Tsubaki and Tsuda (2013), integrated road from one village to 
PLANNING MALAYSIA

Journal of the Malaysia Institute of Planners (2018)

another village or direct routes from the urban areas could attract visitors to visit the rural areas. Other than that, rural areas that are located near to the tourist attractions encourage visitors to visit without the concern on traffic problems that tend to take place in urban areas.

The scenic beauty of the landscape that can be experienced along the rural routes have huge potentials to attract people to travel by choosing the rural routes instead of conventional highways. A study by Aranzabal, Schmitz and Pineda (2009) indicates that the socioeconomic framework to maintain the rural area should relate the aesthetic values of the area and the ecological function. The natural environment and the built environment of the area play important roles to attract tourists.

According to Mizukami et al. (2012), the symbolic values of an area such as special spaces and monuments could act as the landmarks that allow the orientation of space and time. This means that villagers can also play their roles to increase the number of tourists by promoting their unique lifestyle and architectural identity that enhance the sense of place of the rural areas.

In order to attract more visitors to use the rural routes, the facilities and infrastructures need to be upgraded and integrated to more sufficient and functional. One of the mostly used facilities along a driving route is the rest areas (Rehat \& Rawat - RnR), which commonly incorporate petrol station, toilets, prayer rooms, food stalls and parking spaces. Another facility needed by tourists is accommodation, such as hotels or homestays, which could be the rural houses. The tourists could be offered to stay with the local people to experience the rural life.

The natural setting, built environment and infrastructure also contribute to the rural tourism industry (Lo, Mohamad, Songan, \& Yeo, 2012). Natural setting includes forests, hills, beach, and others, as well as agricultural lands. The built environment is composed of traditional houses, landmarks, religious institutions and other structures. Therefore, the scenic beauty of the landscape setting, the facilities and the infrastructure at the rural areas influence the vibrancy of the rural areas along the routes (Table 1).

Table 1: The criteria and indicators of the rural routes

\begin{tabular}{ll}
\hline Criteria & \multicolumn{1}{c}{ Indicator(s) } \\
\hline Quality of scenery & Mountains, lakes, rivers, coastline, panoramic views \\
\hline Strength of attractions & Number of attractions \& quality of each \\
\hline $\begin{array}{l}\text { Potential for recreational } \\
\text { activity }\end{array}$ & Trekking trails, fishing locations, amenities, activities \\
\hline Potential for product clustering & Combined number of attractions, amenities, activities \\
\hline $\begin{array}{l}\text { Range of accommodation } \\
\text { options }\end{array}$ & $\begin{array}{l}\text { Number of different types of accommodation } \\
\text { category }\end{array}$ \\
\hline Range of tourism amenities & Forest recreation area, agricultural parks \\
\hline Distinctive culture and heritage & Number of museum, cultural events, historic links \\
\hline
\end{tabular}


Nur Amirah Abdul Wahab, Khalilah Zakariya, Putri Haryati Ibrahim, \& Illyani Ibrahim

Mapping the Landscape Characters Along A Rural Route for Tourism

\begin{tabular}{ll}
\hline $\begin{array}{l}\text { General services and } \\
\text { infrastructure }\end{array}$ & $\begin{array}{l}\text { Dinning, shopping facilities, TICs, road quality, } \\
\text { water }\end{array}$ \\
\hline Quality of environment & $\begin{array}{l}\text { Absence of litter, water pollution, attractive } \\
\text { streetscape }\end{array}$ \\
\hline Support from official agencies & $\begin{array}{l}\text { Previous tourism investment, efforts to organize } \\
\text { tourism }\end{array}$ \\
\hline Active community organisation & $\begin{array}{l}\text { Local development projects undertaken, sustained } \\
\text { effort }\end{array}$ \\
\hline $\begin{array}{l}\text { Tourism marketing track- } \\
\text { record }\end{array}$ & $\begin{array}{l}\text { Promotional brochures, booking systems, publicity } \\
\text { effort }\end{array}$ \\
\hline $\begin{array}{l}\text { Accessibility to main tourism } \\
\text { centres }\end{array}$ & Within 3 hours travelling time \\
\hline $\begin{array}{l}\text { Proximity to international entry } \\
\text { points }\end{array}$ & Within half a day's travelling time \\
\hline
\end{tabular}

\section{Rural Landscape Character Assessment Criteria}

With reference to the existing landscape characters' assessment frameworks by National Landscape Department (2012), the landscape feature is first categorized in terms of its physiographic character and landform, waterbody and landcover. The identification of landscape characters is important in tourism planning because tourism and environment has a close relationship for conservation and ensuring minimal environmental implication (Prabhakaran, Nair, \& Ramachandran, 2014). The natural environment needs to be conserved as it benefits not only environmentally but economically and socially. Figure 1 shows the components of the rural landscape character assessment that was used as the guideline to collect the data for this study.

Vegetation is another important component that needs to be sustained for rural tourism. The planning of rural tourism considers the landuse, housing, transportation and environmental protection that include the farmers, agriculture and villages (Diao, 2011). On the other hand, the built environment and settlement is also significant to the success of the rural tourism. The built environment of the rural area possesses heritage values, which strengthen the sense of place.

Besides, the human-environment interaction is one of the most important interactions in the cultural landscape that provide the structural and harmonious combination of people and place (Shamsuddin, Sulaiman, \& Amat, 2012). Scenery and sensory of all the landscape features contribute to visitors' experience. As mentioned by (Ghasemi and Hamzah, 2014), the tourist activities such as river cruising, wildlife watching, sunrise and sunset observation could provide scenic and sensory experiences to the tourists. Hands-on activities such as farming and gardening offer new experiences to the tourists to invigorate their visits (Diao, 2011). 
PLANNING MALAYSIA

Journal of the Malaysia Institute of Planners (2018)

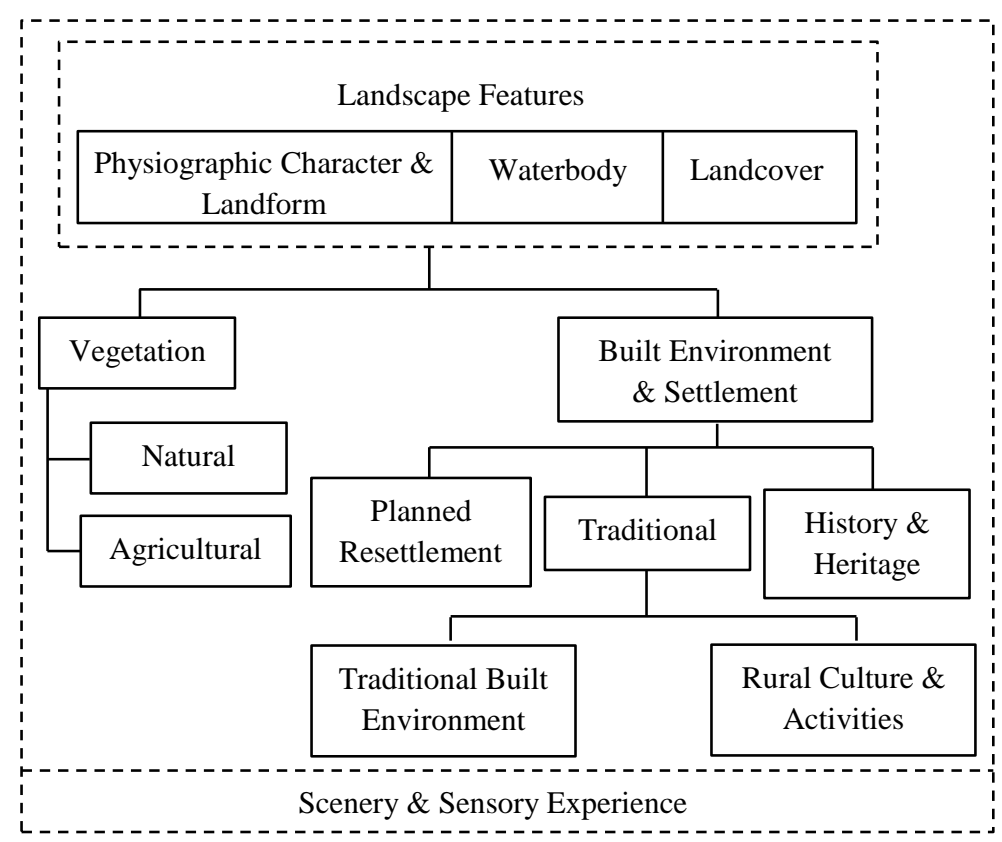

Figure 1: Conceptual framework of rural landscape character assessment Source: Zakariya, Ibrahim, \& Abdul Wahab (2017)

The rural landscape character of the landform, waterbody, landcover, visual sensitivity, visual unity and visual quality will be valued based on the observation. All of the mentioned landscape characters deliver significant values and actions need to be taken for them to be more recognised and preserved.

\section{METHODOLOGY}

The method that is adopted for this study include landscape characters' assessment through a site inventory, observation and landscape character mapping. The site inventory was conducted from Kuala Selangor to Sabak Bernam using Federal Route 5, with a total distance of approximately 64 kilometres. The mapping was done to identify and classify the observed landscape characteristics found along the route. The data collected document the significant landscape features found in the five segments of the route, which then were divided according to the towns where the route passes through. The five segments were: (i) Kuala Selangor, (ii) Tanjung Karang, (iii) Sekinchan, (iv) Sungai Besar, and (v) Sabak Bernam. Other than recording the landscape features using a camera and GPS, the researchers also stopped at any area that was promoted as tourist attractions based on a preliminary study and places that have potentials to attract tourists. The characteristics of the area were inventoried using a checklist that was developed based on the literature review of rural landscape 
Nur Amirah Abdul Wahab, Khalilah Zakariya, Putri Haryati Ibrahim, \& Illyani Ibrahim

Mapping the Landscape Characters Along A Rural Route for Tourism

characters for tourism. The GPS coordinates were then gathered and converted into a map.

\section{RESULTS}

The results of the mapping are explained in a manner that describe the landscape features, vegetation, and built environment and settlement according to the five segments along the route (Figure 2).

\section{Landscape Features}

The major landscape features of Kuala Selangor - Sabak Bernam route is made up of the physiographic characters and landform of the area, which is predominantly of flat land and a hill. Most of the land coverage in Kuala Selangor to Sabak Bernam is flat land, except for Bukit Malawati, a hill that marks the highest point in the area. Bukit Malawati's historical significance has also attracted tourists to visit Kuala Selangor, while at the same time offered tourists to experience the bird's eye view and vista of the whole Kuala Selangor areas and the coast of the Melaka Straits. The main water bodies along these routes are the Selangor River, mirror beach at Kampung Sasaran, Bagan Nakhoda Omar, Pantai Redang and others. This estuary becomes the main source of income to the local people. The majority of the community members in this area work as fisherman. Therefore, tourists could experience the fishing activities and see the lifestyle of the fishermen in this area that maintains the traditional style of fishing activities.

\section{Vegetation}

The study found that Kuala Selangor has abundant vegetation setting. The mangrove area is part of the Kuala Selangor that is rich with biodiversity and scenic nature park, which is already listed as a tourist attraction and has consistently received visits from tourists and visitors. Other than that, agricultural settings along the routes are the coconut and oil palm plantations. These plantations are commonly sighted in the lowland areas of Kuala Selangor, Tanjung Karang and Sabak Bernam area. Majority of the coconut trees are planted near the coastal area, suitable with the sandy soil. On the other hand, the oil palms are planted on the lands beside the routes due to the land suitability of the peat soil. However, the Sekinchan and Sungai Besar area change the views to the paddy and coconut plantations along the routes. Paddy plantations attract visitors since it is well-known at the northern area of Peninsular Malaysia. The paddy fields along this route can be considered to be the closest to an urban area. Another famous attraction of Kuala Selangor is Kampung Kuantan and Buklit Belimbing where visitors can see fireflies that inhabit the Berembang trees (Sonneratia caseolaris). 
PLANNING MALAYSIA

Journal of the Malaysia Institute of Planners (2018)

\section{Built Environment and Settlement}

The Kuala Selangor, Tanjung Karang, Sekinchan and Sungai Besar are the Malay community areas with houses that maintain the rural identity of the area, such as the traditional 'kampung-house' architecture. Kuala Selangor, Tanjung Karang and Sekinchan have the traditional built environment of the Chinese fishermen villages and settlements, especially at the coastal area. The Indian settlements, mostly located near Bukit Rotan, maintains its traditional housing area with scattered settlement pattern. The rural culture and activities in Kuala Selangor and Tanjung Karang can be seen to be practiced by mostly the Chinese and Indian communities. However, the Sekinchan, Sungai Besar and Sabak Bernam areas are starting to be urbanized with presence of terrace houses and high rise buildings as the planned resettlement. Besides the unique rural settlements, Kuala Selangor is also rich with history and heritage. For example, the lighthouse located on top of Bukit Malawati was built in 1907, which previously served the fort. Other than that, the Sri Shakthi Temple located in Bukit Rotan is one of the oldest Hindu temple in Kuala Selangor. This area also has a heritage golf club, which Kelab DiRaja Kampung Kuantan, since 1910 and the building has been conserved until today. The Sekinchan and Sungai Besar area are known for the homestay programs that maintain the rural lifestyle for visitors to experience. There are also many local stalls that promote the local products such as mentarang.

\section{DISCUSSION AND CONCLUSION}

The landscape characters observed along the Kuala Selangor - Sabak Bernam route is found to influence the vegetation, agricultural activities, economic activities, the built environment and eventually the rural lifestyle. The most significant characters along the route are the low landform of the landscape features. This type of geographical setting is dominant in this area. Hence, the local authority and ministry should recognise and control the landuse at this area to be harmonized with the rural landscape.

The less significant character along this route is the history and heritage. Along the routes there are only Bukit Melawati area that has been conserved as a heritage site. The other places are rich with local culture but currently not highlighted as core attractions. Hence, the relevant tourism agencies and local people should work together to promote the history and local heritage in the five areas along the route. 
Nur Amirah Abdul Wahab, Khalilah Zakariya, Putri Haryati Ibrahim, \& Illyani Ibrahim Mapping the Landscape Characters Along A Rural Route for Tourism
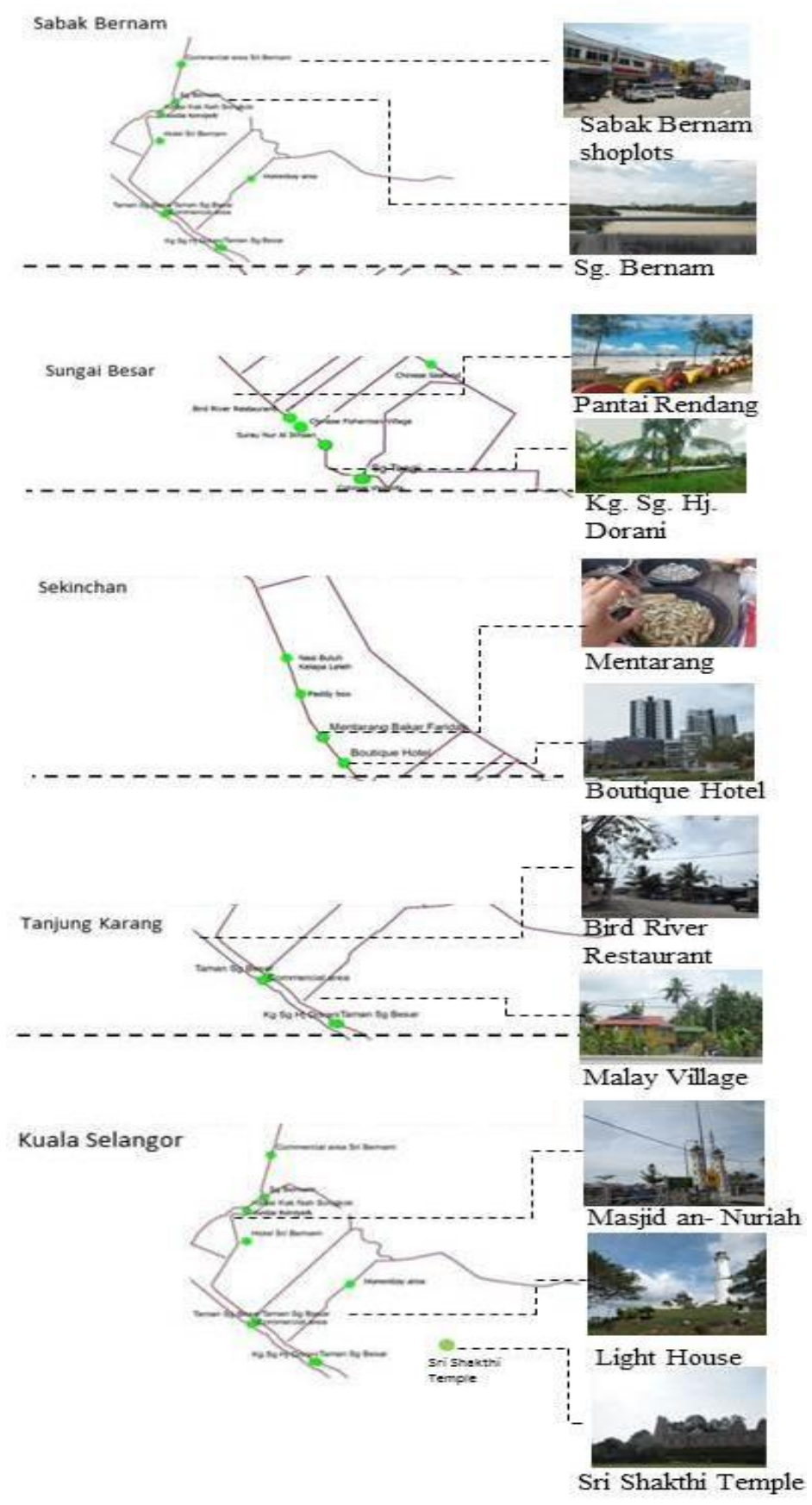

Figure 2: Mapping diagram of rural landscape characters 
For this case study, Bukit Malawati is the landmark of the area because it is the only hill surrounded by flat land and low-land areas. The route is bordered by the same type of agricultural plantations (oil palm and coconut) and intermittently contrasted by the open views towards the paddy fields in Sekinchan and Sungai Besar. Since this route is located on the west-coast of Selangor, it has a distinctive water body image made of the coast, mangrove and the river. The combinations found in these landscape characters are unique because they are influenced by the site's geographic and physiographic characters, which cannot be reproduced elsewhere. Although another place in Malaysia may have the similar landscape characters, nonetheless, the local culture would most likely be different. Hence, all of these characters will attract the visitors to visit the area while increasing the local people's income and promoting the local products.

This study recommends that in order for this area to become a scenic tourism route, activities that relate to its landscape characters can be introduced as a way of strengthening its sense of place. Attractions and stop-points near the road side need to be integrated into the infrastructure, while at the same time, maintaing the setting and ambience of the area. This article concludes by emphasizing that landscape characters are integral in the planning of tourism route.

\section{ACKNOWLEDGEMENT}

This study was supported by the Fundamental Research Grant Scheme under the Ministry of Higher Education Malaysia (FRGS16-018-0517)

\section{REFERENCES}

Aranzabal, I., Schmitz, M. F., \& Pineda, F. D. (2009). Integrating landscape analysis and planning: A multi-scale approach for oriented management of tourist recreation. Environmental Management, 44, 938-951.

Diao Z. (2011) Study on current situation and development strategies for rural tourism in China. In Q. Zhou (Ed.), Advances in applied economics, business and development ISAEBD 2011 (pp. 186-190). Heidelberg: Springer.

Ghasemi, M. \& Hamzah, A. (2014). An investigation of the appropriateness of tourism development paradigms in rural areas from main tourism stakeholders' point of view. Procedia - Social and Behavioral Sciences, 144, 15-24.

Hasuike, T., Katagiri, H., Tsubaki, H., \& Tsuda, H. (2013). Interactive multiobjective route planning for sightseeing on Time-Expanded Networks under various conditions. Procedia Computer Science, 22, 221-230.

Irshad, H. (2010). Rural tourism - An overview. Government of Alberta: Agriculture and Rural Development. 
Nur Amirah Abdul Wahab, Khalilah Zakariya, Putri Haryati Ibrahim, \& Illyani Ibrahim

Mapping the Landscape Characters Along A Rural Route for Tourism

Jaal, Z., \& Abdullah, J. (2012). User's preferences of highway landscapes in Malaysia: A review and analysis of the literature. Procedia - Social and Behavioral Sciences, 36, 265-272.

Mizukami, M. D. G., Ribeiro, L. R. D. C., Sandseter, E. B. H., Ali, S. M., Rostam, K., Awang, A. H., ...\& Ahmad, C. (2012). Towards a compatible landscape in Malaysia: An idea, challenge and imperatives. Procedia - Social and Behavioral Sciences, 15, 70-82.

Lo, M-C., Mohamad, A. A., Songan, P., \& Yeo, A. (2012). Positioning rural tourism: Perspectives from the local communities. International Journal of Trade, Economics \& Finance, 3(1), 59-65.

National Landscape Department (2012). Manual penilaian karakter landskap Malaysia. Kuala Lumpur: Kementerian Perumahan dan Kerajaan Tempatan.

Prabhakaran, S., Nair, V., \& Ramachandran, S. (2014). Community participation in rural tourism: Towards a conceptual framework. Procedia - Social and Behavioral Sciences, 144, 290-295.

Shamsuddin, S., Sulaiman, A. B., \& Amat, R. C. (2012). Urban landscape factors that influenced the character of George Town, Penang Unesco World Heritage Site. Procedia - Social and Behavioral Sciences, 50, 238-253.

Zakariya, K., Ibrahim, P. H., \& Abdul Wahab, N. A. (2017, February). Land scape character assessment for Malaysia's rural landscape: A conceptual framework. Persidangan Kebangsaan Masyarakat, Ruang \& Alam Sekitar (MATRA) 2017. February 23-24, 2017, Penang, Malaysia. 